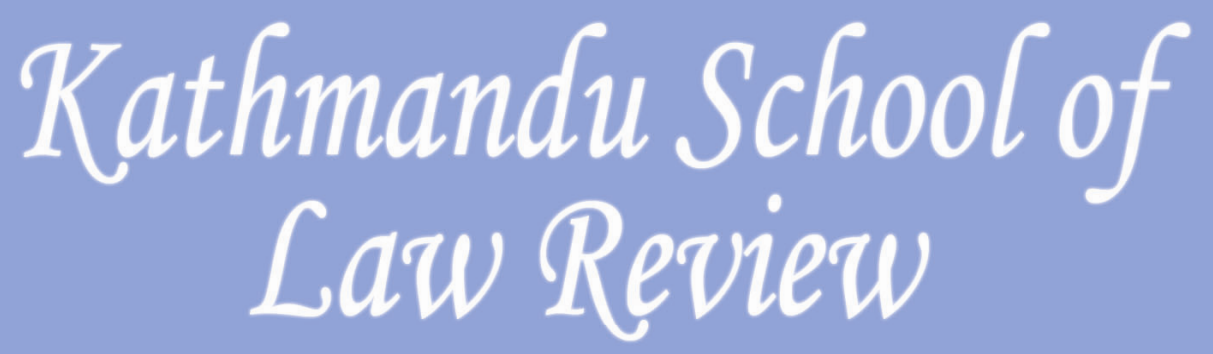

ISSN 2091-2110

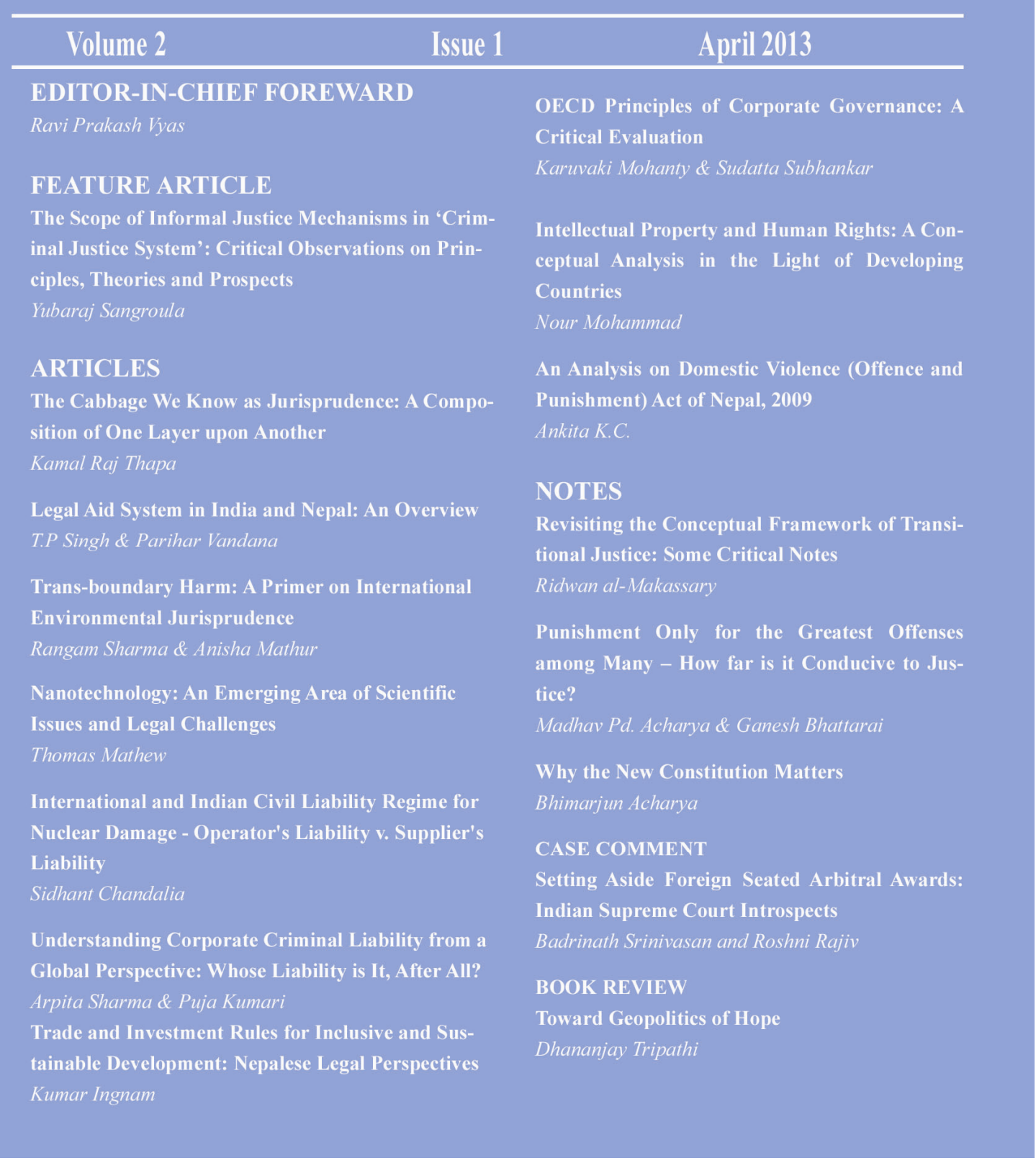




\title{
Trans-boundary Harm: A Primer on International Environmental Jurisprudence
}

\author{
Rangam Sharma ${ }^{1} \&$ Anisha Mathur ${ }^{2}$
}

\begin{abstract}
The paper discusses international jurisprudence in the regime of transboundary harm. Principles of good neighbourliness, due diligence and precaution are major guidelines forwarded by international jurisprudence dealing with trans-boundary problems. The paper examines the current status quo of customary and conventional international law that acts as a tool to combat trans-boundary harm. The paper ponders into the issues of territorial sovereignty, doctrine of necessity and conventional obligations to prevent transboundary harm making extensive use of the judicial and arbitral decisions to throw light on the existing regulations and obligation. The paper concludes that effects of customs, conventions, treaties and other international instruments have led to establishment of effective mechanism to determine the liability and the quantum of liability.
\end{abstract}

\section{Introduction}

The entire international law has been conceptualized within the purview of good neighborliness. Every state has an imperative obligation not to undertake an act or allow activities within their territorial jurisdiction that would stand contrary to the rights of other states. Article 74 of the Charter of United Nations ponders over the principle afore stated and casts a mandate on members to act in consonance to principle of good neighborliness.

Post 1972 world has seen an evolution in the international environmental jurisprudence. This led to the introduction of various principles inter alia sustainable development, precautionary principle, principle of due diligence among others. Today, we have reached a point where prevention of trans-boundary pollution is no more a de lege feranda but has attained a status of custom. Violation of the same is equivalent to an act that contravenes the principles of erga omnes and jus cognes.

An internationally wrongful act is committed by a State only when a conduct consisting of an action or omission is attributable to that $\mathrm{State}^{3}$ under international law and that conduct

BBA LLB student at Symbiosis Law School, Noida.

BA LLB student at Symbiosis Law School, Noida. 
development law is incorporated in a system of norms and rules that, according to ruling doctrines, cannot be considered to be true international law. ${ }^{96}$ In the case of Hungary $v$ Slovakia, the court rejected the binding state of Environmental assessment.

The analysis can be made from the conclusion of the court on these three occasions as follows. Firstly, while the court found that the obligations of the parties in respect of environmental protection arose from the treaty, it implicitly rejected EIA as the norm of the international law, which would be applicable notwithstanding lack of these obligations under the treaty. ${ }^{97}$

The court undermined the precautionary principle by requiring that the environmental consequences must be grave and imminent before the States could suspense the projects. ${ }^{98}$ The court implied that the warnings of environmental consequences are not sufficient. However, by the time of the scientific studies, which show these grave and imminent consequences, the environment may have been largely damaged.

Although the court relied upon the treaty in determining the obligations for environmental protection, it failed to provide the manner, in which the States should comply with these obligations. The court did not express the requirement for the States to conduct the study of the projects, which may have the consequences on the environment. ${ }^{99}$

It opened the possibility that the States may disregard in maintaining the environmental protection unless the treaty incorporated with these obligations. ${ }^{100}$

\section{Conclusion}

It is a fact that the international jurisprudence in the trans-boundary harm regime has come a long way. The effects of customs, conventions, treaties etc have led to establishment of effective mechanism to determine the liability and the quantum of liability. Yet a lot of issues are still to be addressed. Though the broad concepts of erga omnes and jus cognes are now being used in the environmental context too but the soft laws - the vague words used in the treaties create a lot of loopholes and the states across the world get an opportunity to exploit the existing lacunas. Interpretation of treaty in good faith and keeping in view the broad concept of erga omnes can suffice the need for now. As of long hand planning, it becomes imperative for the member nations of UN to come forward and propound multilateral treaties that would ensure the uniformity and would eliminate any ambiguity.

$* * * * * * * * * * * * * * * * * * *$

\footnotetext{
96 See N.J. Schrijver \& E. Hey, 'Volkenrecht en Duurzame Ontwikkeling, Preadviezen, Mededelingen van de Nederlandse Vereniging voor Internationaal Recht' (2003) 6.

97 Gabcikovo-Nagymoros Project Case (n 7).

98 Ibid.

99 Gabcikovo-Nagymoros Project Case (n 7).

100 Ibid.
} 